\title{
Emotional activation measured using the emotional Stroop task in early Hungarian-Serbian bilinguals from Serbia
}

\author{
Beáta Grabovac \\ University of Novi Sad \\ beata.grabovac@magister.uns.ac.rs
}

\section{Csaba Pléh}

Center for Cognition and Communication, and Department of Psychology, Eszterházy College, Eger

pleh.csaba@ektf.hu

\begin{abstract}
The primary goal of this research was to examine the processing of emotionally valenced and neutral words in the context of bilingualism. The objective was to find out, using an experimental measure of automatic emotional activation, if there were differences in response time in the first and the second language, Hungarian and Serbian respectively. The sample consisted of early Hungarian-Serbian bilinguals, assimilated into the Serbian majority culture.

The emotional Stroop task is an experimental paradigm, which has been adapted to measure bilingual population in the past few years. The emotional Stroop interference could be counted from response time latencies, which is usually an effect showing longer responses to negative vs. neutral information.

Hungarian and Serbian negatively, positively and neutrally valenced words were used in the research. Our hypothesis was that there would be a similar emotional activation in the first and the second language and that negative words would be processed the longest.

The result of the research was a significant main effect of word type, where the negative information captured the attention for a longer period of time than the neutral one. A similar pattern of word processing showed in both languages, there were no significant differences between Hungarian and Serbian reaction times and the interaction between word type and language was not significant. The results suggested that early Hungarian-Serbian bilinguals were equally effective and fast in monitoring emotional information in both of their languages, giving emphasis through more elaborative processing to the threatening stimuli.
\end{abstract}

Keywords: emotional Stroop task; negative words; positive words; neutral words; bilingualism; Hungarian; Serbian 


\section{Introduction}

In the last decade, scientists have shown a growing interest in the emotional content expressed in language: emotion and emotion-laden words, metaphors, and language emotionality have recently become very popular topics in psychology and linguistics (Pavlenko 2006; Wierzbicka 2008; Kövecses 1990).

The relations and interplay between language and emotions have been assessed employing various methods: rating procedures (Altarriba 2006), experimental designs (Sutton et al. 2007; Eilola et al. 2007; Eilola \& Havelka 2010b; Winskel 2013), and physiological measures (Harris et al. 2006; Eilola \& Havelka 2010b).

Researchers have so far revealed different potential factors that can affect the expression and subjective experience of emotional content in the first- and the second language: age of language acquisition, frequency of language use, language dominance, proficiency and context of use are just some of them, and they seem to also have a joint effect.

Emotional processing and production through language can be analyzed on different levels of complexity: memories, stories, sentences or words. The results of these studies are not equivocal, some point to differences, whereas others to similarities in bilinguals' affective displays seen through language.

Complex structures like language-specific emotional utterances and stories were analyzed by Koven (2006), who worked with a PortugueseFrench bilingual growing up in France, who used French - the L2 - for public and private interactions, but also Portuguese at home and with her boyfriend. The task was to articulate emotionally charged experiences in each of the two languages. Generally, the results showed that the subject was calmer and more neutral in Portuguese and more "emotionally intense" in French. The conclusion reached was that the same person can be a "different kind of social actor" depending on the language used (ibid., 107).

Kövecses (1990) adopted a different approach by working with complex linguistic stimuli in the form of sentences. Among other linguistic expressions, metaphors and metonyms were used to analyze emotional meaning. Conceptual metaphors can be related/derived from several different metaphors/metonyms and they are the root of many emotional expressions. The author succeeded in connecting basic conceptual metaphors to expressions related to several positive and negative emotions. In Kövecses's opinion, emotion concepts are a valid aspect of reality and a valuable tool for studying the human affective world. Kövecses (2003) also made cross- 
linguistic comparisons: among other things, he found that metaphorical expressions about love in Hungarian and English with a similar superficial meaning could also have different ideological and cultural implications, presumably mirroring different attitudes towards life in the two cultures.

Psycholinguistic research often used single words as stimuli. A very important step in this line of inquiries was the question about the status of emotion words in the mental lexicon. Altarriba et al. (1999) conducted a normative study about the nature of emotion words. They used a word rating task and found that emotion words were between abstract and concrete words regarding imageability and the lowest of the three categories on concreteness and context availability measures. This meant that emotion words could be accounted for as a different class of words in the mental lexicon. In practice, this would imply that emotion words should be treated, used and analyzed separately in experiments and research.

In this field of study difficulties occurred because there were no conventional and widely accepted criteria for the categorization and the selection of emotion words/affectively charged words. A taxonomy of 500 emotion words was construed by Ortony et al. (1987), which was an important step towards systematization of verbal emotional expressions. Since then Bradley and Lang (1999) have provided affective ratings for 1034 English words on the affective dimensions of pleasure, arousal and dominance, and similar databases have been made based on their work in Spanish (Redondo et al. 2007), German (Schmidtke et al. 2014) and European Portuguese (Soares et al. 2012). Word ratings can be also found for 4300 Dutch (Moors et al. 2013), 210 British English and Finnish nouns (Eilola \& Havelka 2010a) and 1482 Serbian words (Janković 2000a;b), but these studies used different methodologies, had various aims and differing theoretical grounds, although all of them investigated qualitative aspects of words or underlying higher order dimensions of words. It should be pointed out that the affective lexicon has been studied extensively in the English language but unfortunately there are many other languages in which similar categorizations and taxonomies have not yet been made.

The topics of language emotionality had been extended to bilingual population. Pavlenko (2006) was the first who raised questions about bilingual and multilingual people's first, second, etc. language emotionality through a fusion of linguistics and the affective sciences. Since then, many researchers have designed studies asking whether and when the first, native language is emotionally more intensive compared to the second one and vice versa. The debate is ongoing: some researchers think that the first, native language has more intensive emotional tone (Deweale 2004), and 
that it is presumably contextually more grounded than the second language (Altarriba 2006), whereas others state that research on bilingualism does not unequivocally support the notion that "the first language is the language of the heart" (Eilola et al. 2007). Javier's (2007, 76) opinion is that an additional feature of affective and abstract information might be that they are "more accessible in relation to the language more closely associated with the development of this specific emotional and abstract information", than concrete words/topics.

In recent times, an experimental design, the emotional Stroop task, has been adapted to measure bilingual populations (Sutton et al. 2007; Eilola et al. 2007; Eilola \& Havelka 2010b; Winskel 2013). The task can show interference due to emotional content. A typical result is that negative emotional information causes a slowdown in reaction time relative to the neutral one (Chajut et al. 2010). The method instructs subjects to ignore the threatening, negative and neutral meaning of the words presented, asking just to name or identify them. It can show if the presence of negative information induces some kind of inhibition or freezing effect visible through longer reaction times to negative stimuli (Algom et al. 2004). The slower responses mean that subjects, who are explicitly instructed to ignore the content of the words, are nevertheless unable to exclude processing of the semantic information of the words seen (Wilson et al. 2007).

Sutton et al. (2007) think that this task is a measure of automatic access of emotion and selective attention to emotional information. The reaction times are something "like skin conductance responses to emotion words" (Sutton et al. 2007, 1080), although there is still an ongoing polemic about the underlying mechanism of the elongation (Algom et al. 2004).

Recently, Ben-David et al. (2012) made an attempt to unravel the processes that lie behind the emotional Stroop effect. In presenting these ideas we must emphasize that they still need testing and additional experimental support. Using a smart experimental design, which was based on accuracy measures, the authors compared two views, the attention and the threat account of the emotional Stroop effect. The first one argues that threatening information captures attention, whereas the latter one presupposes "a temporary freeze on all ongoing activity" in the face of threat (ibid., 537). The Signal Detection Theory was used as a theoretical framework: in a preliminary hypothesis perceptual sensitivity was linked to the threat theory and response bias to the attention account. In practice, this would mean that if the threat account is correct, the "psychological distance" between the colors would become smaller. When subjects were confronted with threatening information, the perceptual ability of detect- 
ing the differences between the colors would be weakened, resulting in "poorer discrimination" (ibid., 540). Additionally, in the second, attention account, the readiness to respond in one or an alternative way was changed: e.g., "favoring one stimulus over the other in responding" (ibid., 537). The authors' results showed that sensitivity to the same ink color was reduced when dealing with emotional words in contrast to neutral ones. Additionally, the response criterion was not significantly altered throughout the negative and neutral blocks. The authors have concluded that these results support the threat account and they also suggest that the emotional Stroop effect is the result of an "instinctive perceptual-motor reaction to threat" (ibid., 540).

The emotional Stroop task has been used with the bilingual population, who had English as one of their languages. There are four studies showing somewhat different results: emotional interference is always present in both or just one language, but speed and accuracy in the first and the second language seems to depend on the type of bilingualism. The results might be also different because these studies used different kinds of words with varying group sizes and disparate experimental designs.

The first research using the emotional Stroop in a bilingual sample was designed by Sutton et al. (2007): they used sixteen negative and sixteen neutral words in an early Spanish-English bilingual, English dominant group. Each subject saw half of the emotion words in Spanish, the other half in English and again half of the neutral words in Spanish, half in English. Their results showed the main effect of word type and language. Emotional interference was present in the expected form: negative words took longer to name. In English language the answers were faster than in native Spanish, so the authors presume that this effect emerged from frequent everyday L2 use and immersion into a second language linguistic community.

The second research conducted by Eilola et al. (2007) started with a hypothesis that late, Finnish dominant bilinguals, who are proficient in English, should show a smaller interference effect in the second language, due to its reduced emotionality. An additional aim was to test if there was a taboo Stroop effect using taboo words, which were assumed to be intensively arousing and connected to physiological changes (Jay et al. 2008). A significant emotional interference was found between negative and neutral and taboo and neutral words. Positive words did not differ from any other group and there were no language effects. Regarding errors there was a significant difference between taboo and neutral words: subjects made more mistakes when they saw taboo words. The authors' main conclusion 
was that the impact of the age of language acquisition was not as important as the proficiency level of a later acquired language for the emotional salience of a language.

Eilola and Havelka (2010b) have continued their work in this field; in a new research they compared English native speakers with Greek-English late, Greek dominant bilinguals. The difference was that only English was tested: in one group as a native and in the other group as a second language. Skin conductance responses were also measured with the aim to compare behavioral measures with physiological ones. The English stimuli were taken over from the experimental design used in 2007. The results showed a word type effect, with no language differences or interaction effects: again, negative and taboo words took longer to name than neutral and positive words. Furthermore, native English subjects were more error prone than the other group. On skin conductance measures a different picture has emerged: there was a significant main effect of word type and the interaction between language background and word type was marginally significant $(p=0.085)$. The analyses of word type differences in the two groups showed that there were higher levels of skin conductance for negative and taboo words than the other word categories in the native speaker group only, but we should mention that taboo words also showed a trend to be significant in the non-native subjects. The interpretation of the obtained results was that in the second language, unbalanced bilinguals are successful in working with the denotative meaning but they do not show an access or activation of the connotative meaning of emotionally charged words in the way as they show in the first language. In conclusion, it seems that the changes in physiological (re)activity are not always mirrored in subjective experience.

Winskel (2013) investigated the effects of language proficiency on emotional interference. Twenty negative and twenty neutral emotion and emotional words were used to compare a native English group from Australia with Thai-English bilinguals from Thailand. Although some of the subjects started to learn the second language early (the age range was between four and ten years) they had all learnt it in an educational setting. The results showed a significant main effect of word type, language and interaction. In the bilingual group, for Thai there were significantly longer reaction times to negative than neutral words, but this was not the case for English. In the English native group, there was also a significant emotional Stroop effect. Proficiency effects were tested in the bilingual group using correlation between English language proficiency test results and the English emotional Stroop effect, but no significant results were obtained. Winskel 
concluded that proficiency acted as an important factor for emotional interference in the first language, but in the case of the second language it might be that the test used to assess the second language proficiency level was not adequate and precise enough.

The results reviewed above show that the most robust effect in bilingual groups is the effect of word type (or the emotional Stroop effect), more specifically, the longer reaction times to negative and taboo words than other categories. The effects of the first- or second language are not unequivocal, they seem to depend on the first and second language learning histories and the joint effects of frequency of language use, contexts of language acquisition/learning and use, age of acquisition, language dominance and language proficiency.

The aim of the current research is to compare two distinctive languages, Hungarian and Serbian using a bilingual sample to see whether threatening stimuli capture the attention in both languages to the same extent. Based on previous results, our hypothesis is that we will find a similar emotional interference in both Hungarian and Serbian because we study early bilinguals immersed into the majority, Serbian culture. We assume that there will be differences between the reactions to negative and neutral words, but not between positive and neutral ones.

The novel contribution of this research is that it compares two languages, which have not been studied in the context of language emotionality. We also use a bilingual sample, which is different in language learning history from the groups compared so far.

\section{Materials and Methods}

\subsection{Subjects}

In the pre-screening procedure we have administered the Hungarian Beck Depression Inventory Short Form (Beck \& Beck 1972, translation by Kopp 2007) and the STAI State-Trait Anxiety Inventory (Spielberger et al. 1970, translation by Sipos \& Sipos 2007a;b), and a shortened version of the Language History Questionnaire ( $\mathrm{Li}$ et al. 2006), which was translated into Hungarian for the purposes of this research.

Subjects who started learning the second language after the age of seven, had high depression/anxiety score or did not know more than seven words were excluded from further analysis.

Overall, after the selection, the sample consisted of thirty-nine subjects. There were nineteen females and twenty males, who had normal 
or corrected-to-normal vision and no known reading disorders. Thirty-six of them were pupils of the Svetozar Marković High School or the Mihajlo Pupin High School in Novi Sad. They obtained an additional subject credit for activity by participating in the research. Additional three subjects were acquaintances of the researcher, coming from various faculty departments in Novi Sad.

The age range fluctuated between fifteen to thirty years $(M=17.717$, $S D=3.516$ ). The wider social and linguistic environment of the subjects was Serbian, which is also the majority language. The subjects were members of a Hungarian minority group or came from linguistically mixed marriages, meaning that they mostly spoke Hungarian or both languages in the family settings. Some acquired both languages since birth. In most cases, the broader social environment and family members were an intensive motivational force for learning the second language, being an important means of getting along successfully later in life and professional development.

The Language History Questionnaire showed that all subjects had started to learn Serbian as their second language before the age of seven ( $M=2.871, S D=2.249)$. The age of seven was used as a critical point, because this was the time when subjects enrolled in the primary school and started learning the second language in educational settings. Harris et al. (2006) used similar criteria in a comparative research measuring skin conductance responses of early and late bilinguals.

On a seven point self-rating scale of the Language History Questionnaire, the following skills were tested: reading-, writing-, speaking ability and comprehension in both languages (see tables 1 and 2).

Table 1: Hungarian language skills

\begin{tabular}{lcccc}
\hline & $\begin{array}{c}\text { Hungarian } \\
\text { reading skill }\end{array}$ & $\begin{array}{c}\text { Hungarian } \\
\text { writing skill }\end{array}$ & $\begin{array}{c}\text { Hungarian } \\
\text { speaking skill }\end{array}$ & $\begin{array}{c}\text { Hungarian } \\
\text { comprehension }\end{array}$ \\
\hline Mean & 6.87 & 6.62 & 6.77 & 6.87 \\
Standard deviation & 0.339 & 0.633 & 0.427 & 0.339 \\
\hline
\end{tabular}

We compared the two languages using a composite language proficiency score: the mean of reading, writing, speaking and comprehension ratings. The difference between the two languages was significant $(t(38)=$ 4.299, $p=0.000$ ), the mean for Hungarian was $M=6.782, S D=0.363$, the mean for Serbian was $M=6.089, S D=0.932$. As shown, the most 
Table 2: Serbian language skills

\begin{tabular}{lcccc}
\hline & $\begin{array}{c}\text { Serbian } \\
\text { reading skill }\end{array}$ & $\begin{array}{c}\text { Serbian } \\
\text { writing skill }\end{array}$ & $\begin{array}{c}\text { Serbian } \\
\text { speaking skill }\end{array}$ & $\begin{array}{c}\text { Serbian } \\
\text { comprehension }\end{array}$ \\
\hline Mean & 6.13 & 6.05 & 5.79 & 6.38 \\
Standard deviation & 1.005 & 1.075 & 1.218 & 0.935 \\
\hline
\end{tabular}

important part of language production, speaking was rated the lowest in the second language. Additionally, it must be pointed out that in both languages the means were around 6 ("very good") and that even the mother tongue abilities did not yield the maximum value 7 ("native like level"). Nine subjects indicated that both Hungarian and Serbian were simultaneously acquired from birth.

Frequency of language use was also checked: the subjects reported speaking Hungarian between $75-100 \%$ of the day, with one subject using it $50 \%$ of the day, while Serbian was used daily $100 \%$ by $12,75 \%$ by 13 , $50 \%$ by $6,25 \%$ by 5 and less than $25 \%$ by 3 speakers. Important to our research is that all but three subjects indicated using Serbian in their family setting.

Based on these findings, we can conclude that the bilingual group consisted of early Hungarian-Serbian bilinguals, with Hungarian as their dominant means of expression and understanding, who are highly proficient in Serbian. Additionally, the subjects were currently living in an environment where the second language, Serbian was the socially dominant language, and they were using it on everyday basis in formal and informal settings as well.

\subsection{Method}

\subsubsection{Materials}

In this research, three different word types were used to create the emotional Stroop task: negative, positive and neutral. In the first step, the Connotative Dictionary was used (Janković 2000a;b) to find words which would belong to the three predefined categories by valence. Initially, fortyone Serbian words were selected, which then were sent to Belgrade in order to obtain their frequencies from the Serbian frequency dictionary Kostić (1999). The Hungarian database, Szószablya ${ }^{1}$ was used to find the frequen-

\footnotetext{
${ }^{1}$ http://szotar.mokk.bme.hu/szoszablya/searchq.php
} 
cies of matching Hungarian words. The process resulted in eighteen words in the negative list, eighteen in the positive and eighteen in the neutral list.

Word frequency was matched for Hungarian using the Szószablya database, and for Serbian using Kostić (1999). The frequency measures were log-transformed because they were not normally distributed: Hungarian negative $(M=-12.275, S D=1.517)$, Hungarian positive $(M=$ $-12.788, S D=1.861)$ and Hungarian neutral $(M=-11.342, S D=$ $1.655)$ words yielded in $F(2,51)=3.412, p=0.041$, where there was a significant difference between the neutral and positive words $p=0.039$. The Serbian negative $(M=-10.857, S D=1.516)$, Serbian positive $(M=$ $-11.565, S D=1.817)$ and Serbian neutral words $(M=-10.421, S D=$ $1.949)$ yielded in $F(2,51)=1.917, p=0.157$. Word length measured by the number of syllables was also matched between word groups. Comparing the length of Hungarian negative $(M=3.333, S D=1.084)$, Hungarian positive $(M=3.111, S D=0.758)$, Hungarian neutral $(M=$ $2.777, S D=1.165)$, Serbian negative $(M=2.833, S D=0.985)$, Serbian positive $(M=3.388, S D=0.777)$ and Serbian neutral words $(M=2.666, S D=1.137)$ for language the test resulted in $F(1,102)=$ $0.334, p=0.564$, for valence category in $F(2,102)=2.629, p=0.077$ and interaction $F(2,102)=1.366, p=0.260$. The arousal and valence dimensions were available just for Serbian words (Janković 2000a;b). On the arousal dimension the Serbian negative $(M=1.242, S D=0.200)$, positive $(M=1.737, S D=0.386)$ and neutral $(M=1.419, S D=0.205)$ words resulted in an $F(2,51)=14.669, p=0.000$, and the post hoc analysis showed that negative and positive $(p=0.000)$ and positive and neutral words $(p=0.004)$ differed significantly from each other, positive words being more arousing.

On the valence dimension the Serbian negative $(M=-2.461, S D=$ $0.188)$, positive $(M=2.435, S D=0.225)$, neutral $(M=0.275, S D=$ 0.214 ) words resulted in an $F(2,51)=2457.694, p=0.000$, and a post hoc analysis showed that each category differed significantly from the other on the level $p=0.000$.

The emotion-laden words used in the experiment were the following (in Hungarian, Serbian and their English glosses). In the negative group: erôszak-agresija 'agression', adósság-dug 'debt', veszteség-gubitak 'loss', árulás-izdaja 'treason', kínzás-mučenje 'torture', tiszteletlenségnepoštovanje 'disrespect', igazságtalanság-nepravda 'injustice', idegességnervoza 'nervousness', baleset-nesreća 'accident', sikertelenség-neuspeh 'failure', veszély-opasnost 'danger', sérülés-povreda 'injury', megcsalás- 
preljuba 'cheat on somebody', szakítás-raskid 'split up', háború-rat 'war', szegénység-siromaštvo 'poverty', pofon-šamar 'slap', verekedés-tuča 'fight'.

The positive list consisted of gondtalanság-bezbrižnost 'ease', jólétblagostanje 'well-being', tisztaság-čistota 'purity', jólelküség-dobrodušnost 'charity', kedvesség-ljubaznost 'kindness', önzetlenség-nesebičnost 'selflessness', gyengédség-nežnost 'tenderness', ünnep-praznik 'celebration', tökély-savršenstvo 'perfection', biztonság-sigurnost 'safety', megkönnyebbülés-olakšanje 'relief', szabadság-sloboda 'freedom', megértés-razumevanje 'understanding', melegség-toplina 'warmth', nyugalom-smirenost 'calmness', kényelem-udobnost 'comfort', édesség-umiljatost 'sweetness', élvezet-uživanje 'pleasure'.

The list of the neutral words was as follows: gyorsaság-brzina 'fastness', bizonyíték-dokaz 'proof', kivétel-izuzetak 'exception', kard-mač 'sword', szokás-navika 'habit', kötelezettség-obaveza 'commitment', osztályzat-ocena 'grade', fennmaradás-opstanak 'survival', ellenállás-otpor 'resistance', javitás-popravljanje 'reparation', kamaszkor-pubertet 'puberty', áram-struja 'current', biró-sudija 'judge', ellenkezés-suprotstavljanje 'opposition', hír-vest 'news', hatalom-vlast 'power', törvény-zakon 'law', tél-zima 'winter'.

\subsubsection{Procedure}

The testing was done individually. All subjects filled in the questionnaires about their language proficiency, the Beck Depression Inventory Short Form and the STAI State-Trait Anxiety Inventory.

The experimental part was done on a Samsung Ativ Book 6670 laptop with a custom made experimental program (this was supported by a project of the Ministry of Serbia, number III47013). The procedure resembled the one used by Sutton et al. (2007) with elements of the one used by Eilola et al. (2007). Words were shown on a white background, the font size was 100 points with a 72-dpi resolution, type Times New Roman. Four colors were used: red, blue, green and yellow.

The words were blocked, organized into categories by valence: there were separate blocks with positive, blocks with negative and separate blocks with neutral words. The tasks had two parallel versions, one in Hungarian and one in Serbian, so language was also blocked: some of the subjects saw the Hungarian task first, and then the Serbian, while the others did it the other way around.

The order of the tasks was counterbalanced and the words and colors were randomized. Each word was presented only once. The instructions were the following: You will see different words in different colors. Your 
task is to choose and press the button on the keyboard, which has the same color label as the color of the word seen. The aim is to respond as fast and as accurate as you can by pressing the matching button (green, blue, red or yellow), while ignoring the meaning of the word.

The explanation was afterwards repeated orally and subjects were told that they would see words both in Hungarian and Serbian. When the subjects felt that they were ready to start the experiment, they completed six practice trials in both languages with words that were not used later in the procedure. Afterwards, there was a little pause to discuss whether everything was clear and if the real experiment could start. In the experimental part, the fixation cross, in the form of a + sign appeared on the screen for $300 \mathrm{~ms}$ before the stimulus word. Then the colored words were shown until the subjects responded. In the following section, a fixation cross again signalized the next target word. Subjects used the "V" key with a yellow, the "B" key with red, the "N" key with blue and the "M" key with green labels for providing the answers. If the word presented was blue, subjects had to push the blue button and if it was green, the green button, etc. If the subjects made a mistake, the "Wrong answer!" sentence appeared and if the answer was the right one, then the "Right answer" message was shown. They were also told to try to answer accurately, but also as fast as they can. After the experiment, the subjects were given a list containing all of the words, where they could indicate if they had problems with comprehension. As a final step words were rated for emotional valence, but due to space limits, we will not report these results here.

\section{Results}

\subsection{Analysis of errors}

The erroneous answers, which accounted for $2.7 \%$ of all results, were analysed separately. The average error rate was $M=0.027, S E=0.005$. A two-way within-subjects ANOVA was conducted with two factors: Word Type (negative, positive, neutral) and Language (Hungarian, Serbian). The main effect of language was $F(1,38)=0.276, p=0.602$, the main effect of word type $F(2,76)=2.277, p=0.110$ and the interaction $F(2,76)=0.288, p=0.706$ (in the case of interaction, a GreenhouseGeisser correction was used, because sphericity was violated). There were no significant differences between word categories, nor between languages regarding errors and mistakes in the answers. 


\subsection{Analysis of response latencies}

Only the correct answers were included in the analysis of response latencies. The reaction times included in this further analysis were not smaller than $300 \mathrm{~ms}$ or greater than $1500 \mathrm{~ms}$. The analysis was conducted on negative Hungarian, positive Hungarian, neutral Hungarian and negative Serbian, positive Serbian, neutral Serbian mean reaction times for each subject. A two-way within-subjects ANOVA with two factors: Word Type (negative, positive, neutral) and Language (Hungarian, Serbian) was used.

There was a significant main effect of Word Type: $F(2,76)=4.236$, $p=0.018$, partial $\eta^{2}=0.100$. The mean reaction time for negative words was $M=719.631, S E=13.270$, for positive words $M=716.475, S E=$ 13.646 and for neutral words $M=701.310, S E=14.012$ (see figure 1, where the difference between the dark gray bars is a significant difference). The pair-wise comparisons showed that there is a significant difference between negative and neutral words $p=0.007$, whereas there are no significant differences between negative and positive words $p=1.000$ and positive and neutral words $p=0.120$.

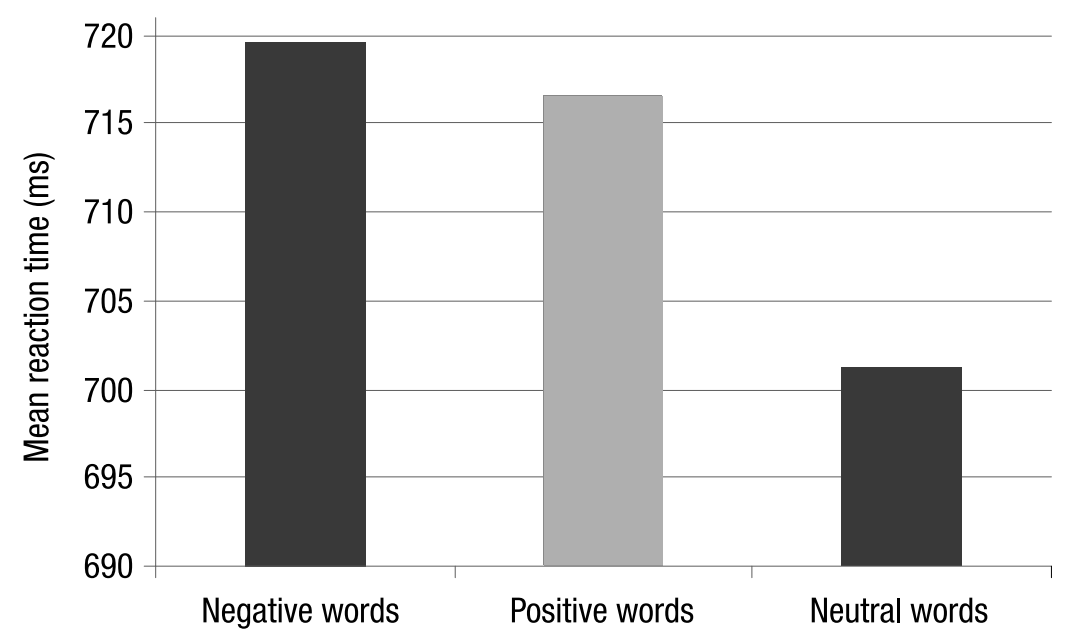

Figure 1: Mean reaction times (ms) for negative, positive and neutral words

The Language factor as a main effect was not significant, $F(1,38)=$ $0.023, p=0.879$, partial $\eta^{2}=0.001$. The interaction between Word Type and Language did not yield a significant result, $F(2,76)=0.456, p=$ 0.636, partial $\eta^{2}=0.012$. 


\section{Discussion}

In the emotional Stroop task meaning is processed automatically and fast (Eilola et al. 2007), and it has been proposed that in word processing we can distinguish between physiological, "somatovisceral responses" or "affective processing" and processing of the "affective valence" or "semantic processing" of words (Pavlenko 2012, 416, 423) and the emotional Stroop task seems to tap valence effects only.

The aim of this research was to compare early Hungarian-Serbian bilinguals in the automatic processing of emotionally valenced and neutral words in their two languages.

The research revealed a significant difference in responding to negative and neutral words, meaning that there is an emotional Stroop effect: negative information captured the attention and had a greater impact on the subjects than seeing neutral stimuli. Also, the effect seems to be independent of the language used by early bilinguals: between-language analysis of response latencies did not show a significant difference. We can thus conclude that the word processing and the pattern of interference were similar in the two languages and that there was no prioritized language for working with emotion-laden words.

Comparing the sample used in this research with the ones used in the prior four studies using the bilingual emotional Stroop task we can say that our group showed resemblance to the one used by Sutton et al. (2007) based on the language history measures. The similarities were that they investigated early bilinguals, highly proficient in both of their languages, but a difference was that their subjects had their second language as the dominant one. In this research the subjects were highly proficient in their second language, they were living in an L2 environment, the acquisition/learning of the language also had an early start and subjects were dominant in their native language. Sutton et al. (2007) obtained significant emotional Stroop effect and language differences as well. The effect was smaller in the first, non-dominant language and faster reaction times were found in the dominant, but second language. Important to note is that in the research by Sutton et al. (2007) the second language was the language of the environment and subjects used it $81 \%$ of the day. They interpreted their results in the context of frequency of L2 use and proficiency level and they believe that these factors contribute the most to language emotionality and interference size. The results of our research are in line with the opinion of Sutton and colleagues, because in our sample the bilinguals included used their second language on a daily basis, some of them 
interchangeably during the day, and also, they were immersed into a majority, second-language speaking environment.

The other three studies that measured the emotional effects worked with late bilinguals, who started to learn the second language at the age of 6-7 or later (Eilola et al. 2007; Eilola \& Havelka 2010b) and in formal, educational settings (Winskel 2013). Eilola et al. (2007) and Eilola and Havelka (2010b) have found mutually concurring results: a significant effect of word type, and non-significant effects of language and interaction. This means that in both cases the subjects showed a "negativity/threat" bias, or emotional Stroop effect, but also that they were not affected by first- or second language activation in responding to the colors. Returning to early bilinguals, Harris et al. (2006) think that in early bilingual groups the emotional activation of the languages can be of the same size: if proficiency is at similar levels or the first learned language is actually less proficient. In their research, they measured skin conductance responses during a pleasantness rating task using neutral, aversive and positive words, endearments, insults, reprimands and taboo words, and found no differences between the L1 and L2 words in early L2-dominant bilinguals. It must be added that late bilinguals also showed differential processing only in the case of childhood reprimands. Harris et al. (2006) believe that the highly emotional context of language learning is the determining and crucial factor of language emotionality. If the emotional transactions are a natural part of childhood language use, these languages become associated with emotional valence. Moreover, Harris et al. (2006) believe that language emotionality is not an exclusive characteristic of childhood language learning and acquisition; it can be also reshaped later in life through intimate relationships and emotional interactions and verbal exchange.

Based on these opinions, the early bilingual sample of this research might have developed a similar emotionality on the level of semantics in the first and second language as well, due to interpersonally and emotionally salient contexts of childhood language learning through frequent communications with family and friends. The context-of-learning theory proposed by Harris and her colleagues is consistent with the pattern found because natural contexts of learning led to similar activation of both languages.

A popular model of bilingual language processing is the Revised Hierarchical Model, which was proposed by Kroll \& Stewart (1994). The model assumes that there are independent representations for the L1 and L2 words with a shared conceptual store, that the L1 is more strongly linked to the conceptual store than the L2 and that on the lexical level L2 would activate more easily the L1 words than vice versa (Schwartz \& Kroll 
2006). The model has been criticized since because converging empirical data have supported language nonselectivity contrary to the hypothesized existence of two distinct lexicons formulated by the model. This question is still open, and Kroll et al. (2010) argue that bilinguals might have separate lexicons with paralell access to content. The model is developmental and suggests that growing proficiency changes the functioning of the two languages. Proficient bilinguals do not use translation equivalents from the L1 to work with L2 words (Kroll et al. 2010). Kroll and Sunderman (2003) believe that proficiency is the key factor, which can lead to concept mediation in the second language and that this factor also ensures that the L2 links to concepts become more similar as in L1 (Schwartz \& Kroll 2006).

Eilola et al. (2007) pointed out that, based on the Revised Hierarchical Model, the L1 should produce a bigger emotional Stroop effect than the L2 due to stronger links with the conceptual system, faster activation of meaning and also less interference in the L2 in late bilinguals. Nevertheless, their results did not support this theoretical assumption showing the same effect in both languages, which was explained by high levels of proficiency in both languages.

Our subjects were early bilinguals, who used their languages on a daily basis. They did not show differences in the first and second language processing speed, thus words were accessed equally fast, independent of the activated language and valence was also processed in both languages. We assume that our data support the proposal that there are similar L2 links to concepts as in L1 in early bilinguals. This further confirms proficiency effects and the effect of frequent language use on language emotionality.

The value of this research lies in the fact that it extends the results regarding bilingual emotional activation. We have used specific languages, Hungarian and Serbian in the emotional Stroop task, which were not directly compared until now. Also, we have worked with a special type of subjects: an early, Hungarian-dominant sample currently immersed into the linguistic and cultural environment of their second language.

In the future, the authors plan to conduct a similar research with late Hungarian-Serbian bilinguals and to use the Stroop task as well, to see whether there are differences in executive functioning of various types of Hungarian-Serbian bilinguals. 


\section{Acknowledgments}

The authors are grateful to Aleksandar Kostić, a full professor in psychology from the Faculty of Philosophy in Belgrade for his assistance with Serbian word frequencies, and to Dragan Janković for giving access to the Serbian Connotative Dictionary.

The paper was supported by the Ministry of Serbia, project number III47013.

\section{References}

Algom, Daniel, Eran Chajut and Schlomo Lev. 2004. A rational look to the emotional Stroop phenomenon: A generic slowdown, not a Stroop effect. Journal of Experimental Psychology: General 133. 323-338.

Altarriba, Jeanette. 2006. Cognitive approaches to the study of emotion-laden and emotion words in monolingual and bilingual memory. In Pavlenko (2006, 232-256).

Altarriba, Jeanette, Lisa M. Bauer and Claudia Benvenuto. 1999. Concreteness, context availability, and imageability ratings and word associations for abstract, concrete, and emotion words. Behavior Research and Methods, Instruments \& Computers 31. 578-602.

Beck, T., Aaron and W. Beck, Robert. 1972. Shortened version of BDI. Postgraduate Medicine 52. 81-85.

Ben-David, Boaz M., Eran Chajut and Daniel Algom. 2012. The pale shades of emotion: A signal detection theory analysis of the emotional Stroop task. Psychology 3. 537541.

Bradley, Margaret M. and Peter J. Lang. 1999. Affective norms for English words (ANEW): Instruction manual and affective ratings (Technical Report C-1, The Center for Research in Psychophysiology). Florida, MI: University of Florida.

Chajut, Eran, Yaniv Mama, Leora Levy and Daniel Algom. 2010. Avoiding the approach trap: A response bias theory of the emotional Stroop effect. Journal of Experimental Psychology: Learning, Memory, and Cognition 36. 1567-1572.

Deweale, Jean-Marc. 2004. The emotional force of swearwords and taboo words in the speech of multilinguals. Journal of Multilingual and Multicultural Development 25. 204-222.

Eilola, Tiina M. and Jelena Havelka. 2010a. Affective norms for 210 British English and Finnish nouns. Behavior Research Methods 42. 134-140.

Eilola, Tiina M. and Jelena Havelka. 2010b. Behavioural and physiological responses to the emotional and taboo Stroop tasks in native and non-native speakers of English. International Journal of Bilingualism 15. 353-369.

Eilola, Tiina M., Jelena Havelka and Dinkar Sharma. 2007. Emotional activation in the first and second language. Cognition and Emotion 21. 1064-1076.

Harris, Catherine L., Jean Berko Gleason and Ayse Aycicegi. 2006. When is a first language more emotional? Psychophysiological evidence from bilingual speakers. In Pavlenko (2006, 257-28).

Janković, Dragan. 2000a. Konotativni aspekt značenja: konstrukcija konotativnog diferencijala [Connotative aspect of meaning: Construction of the connotative differential]. Psihologija 33. 221-338.

Acta Linguistica Hungarica 61, 2014 
Janković, Dragan. 2000b. Konotativni aspekt značenja: utvrđivanje latentnih dimenzija [Connotative aspect of meaning: Establishing the latent dimensions]. Psihologija 33. 199-221.

Javier, A. Rafael. 2007. The bilingual mind. New York: Springer.

Jay, Timothy, Catherine Caldwell-Harris and Krista King. 2008. Recalling taboo and nontaboo words. The American Journal of Psychology 121. 83-103.

Kopp, Mária. 2007. Beck depresszió kérdőív [Beck depression questionnaire]. In Perczel Forintos et al. (2007, 44).

Kostić, Đorđe. 1999. Frekvencijski rečnik savremenog srpskog jezika [Frequency dictionary of contemporary Serbian]. Belgrade: Institute for Experimental Phonetics and Speech Pathology \& Laboratory of Experimental Psychology, University of Belgrade. www.serbiancorpus.edu.rs

Koven, Michéle. 2006. Feeling in two languages: A comparative analysis of a bilinguals affective displays in French and Portuguese. In Pavlenko (2006, 84-117).

Kövecses, Zoltán. 1990. Emotion concepts. Berlin \& New York: Springer.

Kövecses, Zoltán. 2003. Language, figurative thought, and cross-cultural comparison. Metaphor and Symbol 18. 311-320.

Kroll, F., Judith and Erika Stewart. 1994. Category interference in translation and picture naming: Evidence for asymmetric connections between bilingual memory representations. Journal of Memory and Language 33. 149-174.

Kroll, Judith F., Janet G. van Hell, Natasha Tokowicz and David W. Green. 2010. The Revised Hierarchical Model: A critical review and assessment. Bilingualism: Language and Cognition 13. 373-381.

Kroll, Judith F. and Gretchen Sunderman. 2003. Cognitive processes in second language learners and bilinguals: The development of lexical and conceptual representations. In C. J. Doughty and M. H. Long (eds.) The handbook of second language acquisition. Malden, MA \& Oxford: Blackwell. 104-129.

Li, Ping, Sara Sepanski and Xiaowei Zhao. 2006. Language history questionnaire: A webbased interface for bilingual research. Behavior Research Methods 38. 202-210.

Moors, Agnes, Jan de Houwer, Dirk Hermans, Sabin Wanmaker, Kevin van Schie, AnneLaura van Harmelen, Maarten de Schryver, Jeffrey de Wynne and Marc Brysbaert. 2013. Norms of valence, arousal, dominance, and age of acquisition for 4,300 Dutch words. Behavior Research Methods 45. 169-177.

Ortony, Andrew, Gerald Clore and Mark A. Foss. 1987. The referential structure of the affective lexicon. Cognitive Science 11. 341-364.

Pavlenko, Aneta (ed.). 2006. Bilingual minds. Clevedon: Multilingual Matters.

Pavlenko, Aneta. 2012. Affective processing in bilingual speakers: Disembodied cognition? International Journal of Psychology 47. 405-428.

Perczel Forintos, D., Gy. Ajtay and Zs. Kiss (eds.). 2007. Kérdőívek és becslőskálák a klinikai pszichológiában [Questionnaires and scales in clinical psychology]. Budapest: Semmelweis Kiadó.

Redondo, Jaime, Isabel Fraga, Isabel Padrón and Monsterrat Comesaña. 2007. The Spanish adaptation of ANEW (affective norms for English words). Behavior Research Methods 39. 600-605. 
Schmidtke, David S., Tobias Schröder, Arthur M. Jacobs and Markus Conrad. 2014. ANGST: Affective norms for German sentiment terms, derived from the affective norms for English words. Behavior Research Methods. Advance online publication.

Schwartz, Ana I. and Judith F. Kroll. 2006. Language processing in bilingual speakers. In M. J. Traxler and M. A. Gernsbacher (eds.) Handbook of psycholinguistics. London \& Amsterdam: Elsevier/Academic Press. 967-999.

Sipos, Kornél and Mihály Sipos. 2007a. Állapot szorongás kérdőív [State anxiety inventory]. In Perczel Forintos et al. (2007, 9).

Sipos, Kornél and Mihály Sipos. 2007b. Vonás szorongás kérdőív [Trait anxiety inventory]. In Perczel Forintos et al. (2007, 10).

Soares, Ana Paula, Monsterrat Comesaña, Ana P. Pinheiro, Alberto Simões and Carla Sofia Frade. 2012. The adaptation of the affective norms for English words (ANEW) for European Portuguese. Behavior Research Methods 44. 256-269.

Spielberger, D., Charles, L. Gorsuch, Richard and E. Lushene, Robert. 1970. Manual for the State-Trait Anxiety Inventory. Palo Alto, CA: Consulting Psychologist Press.

Sutton, Tina M., Jeanette Altarriba, Jennifer L. Gianico and Dana Basnight-Brown. 2007. The automatic access of emotion: Emotional Stroop effects in SpanishEnglish bilingual speakers. Cognition and Emotion 21. 1077-1090.

Wierzbicka, Anna. 2008. A conceptual basis for research into emotions and bilingualism. Bilingualism, Language and Cognition 11. 193-195.

Wilson, Edward J., Colin MacLeod and Lynlee W. Campbell. 2007. The informationprocessing approach to emotion research. In J. A. Coan and J. J. B. Allen (eds.) Handbook of emotion elicitation and assessment. Oxford: Oxford University Press. $184-202$.

Winskel, Heather. 2013. The emotional Stroop task and emotionality rating of negative and neutral words in late Thai--English bilinguals. International Journal of Psychology 48. 1090-1098. 